\title{
Author Correction: An assay for the identification of Plasmodium simium infection for diagnosis of zoonotic malaria in the Brazilian Atlantic Forest
}

\begin{abstract}
Denise Anete Madureira de Alvarenga $(\mathbb{D}$, Richard Culleton, Anielle de Pina-Costa, Danielle Fonseca Rodrigues (1), Cesare Bianco Jr., Sidnei Silva, Ana Júlia Dutra Nunes, Julio César de Souza Jr., Zelinda Maria Braga Hirano, Sílvia Bahadian Moreira, Alcides Pissinatti, Filipe Vieira Santos de Abreu, André Luiz Lisboa Areas, Ricardo Lourenço-de-Oliveira, Mariano Gustavo Zalis, Maria de Fátima Ferreira-da-Cruz, Patricia Brasil, Cláudio Tadeu Daniel-Ribeiro \& Cristiana Ferreira Alves de Brito (1)
\end{abstract}

Correction to: Scientific Reports https://doi.org/10.1038/s41598-017-18216-x, published online 08 January 2018

The original version of this Article omitted an affiliation for Anielle de Pina-Costa. The correct affiliations for Anielle de Pina-Costa are listed below:

Laboratório de Doenças Febris Agudas, Instituto Nacional de Infectologia Evandro Chagas (INI), Fiocruz, Rio de Janeiro/RJ, 21040-360, Brazil

Centro de Pesquisa, Diagnóstico e Treinamento em Malária (CPD-Mal), Fiocruz, Rio de Janeiro/RJ, 21040-360, Brazil

Laboratório de Pesquisa em Malária, Instituto Oswaldo Cruz (IOC), Fiocruz, Rio de Janeiro/RJ, 21040-360, Brazil

Centro Universitário Serra dos Órgãos (UNIFESO), Teresópolis/RJ, 25964-004, Brazil

This has now been corrected in the HTML and PDF versions of this Article, and in the accompanying Supplementary Information.

(i) Open Access This article is licensed under a Creative Commons Attribution 4.0 International (c) License, which permits use, sharing, adaptation, distribution and reproduction in any medium or format, as long as you give appropriate credit to the original author(s) and the source, provide a link to the Creative Commons license, and indicate if changes were made. The images or other third party material in this article are included in the article's Creative Commons license, unless indicated otherwise in a credit line to the material. If material is not included in the article's Creative Commons license and your intended use is not permitted by statutory regulation or exceeds the permitted use, you will need to obtain permission directly from the copyright holder. To view a copy of this license, visit http://creativecommons.org/licenses/by/4.0/.

(c) The Author(s) 2019 